Gordon, A. H., Martin, A. J. P. \& Synge, R. L. M. (1944). Biochem. J. 38, 65.

Lester Smith, E. (1942). Biochem. J. 36, Proc. xxii.

Liddell, H. F. \& Rydon, H. N. (1944). Biochem. J. 38, 68.

Martin, A. J. P. \& Synge, R. L. M. (1941). Biochem. J. 35, 1358.
Pickett, M. J., Ley, H. L. \& Zygmuntowicz, N. S. (1944). J. biol. Chem. 156, 303.

Schicktanz, S. T., Steele, W. I. \& Blaisdell, A. C. (1940). Industr. Engng Chem. (Anal. ed.), 12, 320.

Smith, H. W. \& White, T. A. (1929). J.phys.Chem. 33, 1953.

Werkman, C. H. (1930). Industr. Engng Chem. (Anal. ed.), 2, 302.

\title{
The Action of Arsine on Blood
}

\section{OBSERVATIONS ON THE NATURE OF THE FIXED ARSENIC}

\author{
By A. F. GRAHAM, T.'B. B. CRAWFORD AND G. F. MARRIAN, Departments \\ of Medical Chemistry and of Materia Medica, University of Edinburgh
}

(Received 31 December 1945)

A striking feature of poisoning by the inhalation of arsine is the haemolysis which occurs after a short latent period. It is known that arsine is 'fixed' in some non-volatile form by blood in the presence of oxygen and that this 'fixation' may be accompanied by changes in the colour and spectroscopic characteristics of the blood pigment, but little is known with certainty regarding the chemical changes involved in these phenomena and no satisfactory explanation of the mechanism of the haemolysis has been advanced.

That oxygen plays an essential part in the chemical changes was first indicated by Naunyn (1868), who showed that in its absence haemolysis did not occur in blood treated in vitro with arsine. This observation was repeatedly confirmed, e.g. by Meissner (1913), who recognized that arsine is fixed by blood in a non-volatile form in the presence of oxygen. He ascribed this fixation to oxidation to arsenious or arsenic acid, or to the formation of a complex compound, and discovered the important fact that haemoglobin is the only constituent of blood which will react vigorously with arsine. That the fixed arsenic is largely confined to the erythrocytes up to the time of commencement of haemolysis was made clear by the experiments of Thauer (1934), and this has been confirmed in experiments preliminary to the present work.

The chemical nature of the fixed arsenic formed in blood was considered as early as 1865 by Eulenberg, who examined the blood of an arsine-poisoned cat, and on the basis of precipitation experiments with magnesia mixture reported that arsenious acid but not arsenic acid was present. The use of such methods for the detection of small amounts of arsenious and arsenic acids in animal experiments was criticized by Joachimoglu (1916). Stricker (1882) also reported that arsine is oxidized in blood to arsenious acid, but we have been unable to consult the original work.
Labes $(1928,1937)$ suggested that in the presence of oxygen arsine becomes oxidized within the erythrocyte to colloidal elementary arsenic, which he supposed to be the active haemolytic agent. He observed that colloidal solutions of elementary arsenic haemolyze erythrocyte suspensions, but presented no direct evidence that intracellular colloidal arsenic is formed when blood is treated with arsine.

Extensive studies of arsine fixation by haemoglobin and of the nature of the haemolytic agent have been made by Heubner and his co-workers, who allowed whole blood, erythrocyte suspensions, or haemoglobin solutions to react with arsine in the presence of oxygen. From the arsenic content of the reaction products and from the amount of oxygen utilized surmises as to the probable nature of the fixed arsenic were made. Heubner \& Wolff (1936) considered that arsenic dihydride $\left(\mathrm{AsH}_{2}\right)_{2}$, was first formed and that this compound was the haemolytic agent. Their figures further indicated that the final product of oxidation of arsine in the presence of haemoglobin was arsenious acid. Wolff (1936) agreed that this was the final product, but suggested that the intermediate compound was hydroxyarsine $\left(\mathrm{AsH}_{2}-\mathrm{OH}\right)$. Gebert (1937) suggested that arsenic dihydride was formed as an intermediate in the oxidation of arsine to elementary arsenic, the latter being eventually further oxidized to 'arsenik'.

These conclusions of Labes and of the Heubner school seem to be coloured by the assumption that an oxidation product of arsine must necessarily be the direct haemolytic agent.

In the present work an attempt has been made to gain a further insight into the chemical mechanisms involved in the arsine-blood reaction, by a direct examination of the properties and behaviour of the fixed arsenic formed in the blood of arsinepoisoned rabbits, and in normal rabbit blood and haemoglobin solutions treated in vitro with arsine. 


\section{EXPERIMENTAL}

\section{Methods}

Arsenic determination. Total arsenic was determined by the micro-method of Levvy (1943). Samples contained 10-30 $\mu \mathrm{g}$. As. Analyses were carried out in duplicate or triplicate. The figures shown in the tables were calculated from the means of the values obtained.

Technique of animal experiments. Rabbits were exposed to the desired concentration of arsine in air in a specially designed chamber which permitted the instantaneous exposure of the animal to the full concentration of gas and its instantaneous withdrawal to an uncontaminated atmosphere after the exposure period. Each animal was immediately stunned by a blow on the head and rapidly bled, by slitting its throat, into a large beaker surrounded by ice. In some cases the blood was defibrinated with a wire brush; in other cases clotting was prevented by injecting the animals with heparin before stunning and bleeding them into beakers containing more heparin. After measuring the volume of blood, samples (usually $1 \mathrm{ml}$.) were withdrawn for determinations of total As and of percentage haemolysis; the remainder was then laked by the addition of 2 vol. of distilled water. In no instance was any haemolysis detectable in the freshly drawn blood up to the time of laking. Stromata were removed as completely as possible from the laked blood (henceforward referred to as 'the haemolysate') by centrifuging.

Technique of in vitro experiments with blood. Blood from a heparinized rabbit was placed in a $500 \mathrm{ml}$. roundbottomed flask fitted with a rubber stopper through which was passed a short glass tube. A 2 in. length of thin-walled rubber tubing was fitted over the external end of the glass tube, and the other end of the rubber tube closed by a glass rod. The vessel was submerged in a constant-temperature bath at $37^{\circ}$ and the arsine injected by hypodermic syringe through the rubber tubing into the flask. After shaking at $37^{\circ}$ for 5-10 min. any unreacted arsine was removed by thorough evacuation. After removal of samples for analysis, haemolysates were prepared as described above.

\section{Dialysis of haemolysates obtained from arsine-poisoned blood}

In an attempt to obtain information as to whether the fixed As in the erythrocyte is merely a simple oxidation product of arsine, or whether it is in the form of a complex with one of the cell constituents, an extensive series of quantitative experiments on the dialysis of haemolysates prepared from arsinepoisoned rabbits and from normal rabbit blood treated in vitro with arsine was carried out. The only previous reference to any similar work which can be traced is the following statement by Heubner \& Wolff (1936): 'Bei der Dialysen einer mit Arsenwasserstoff behandelten Blutprobe geht ins Dialysat nicht viel weniger Arsen über als aus einer gleichen mit Arsenik versetzen Probe.' No experimental details of this work were reported, and no further reference to it has been made in later papers from Heubner's laboratory.

After removal of samples from each haemolysate for the determination of total As, additional samples (usually $3 \mathrm{ml}$.) were placed in small dialysis sacs made from 'Visking' synthetic sausage casing (c. 3 in. diam.) and dialyzed for $48 \mathrm{hr}$. in the refrigerator against four changes of $100 \mathrm{ml}$. water. The As remaining in each sac and its contents was then determined, blank determinations being simultaneously carried out on empty sacs.

Preliminary experiments showed that under these conditions of dialysis, the dialyzable As is completely removed from haemolysates of arsinepoisoned blood in less than $48 \mathrm{hr}$. The results from fourteen experiments on arsine-poisoned rabbits (Table 1) and from eight experiments with the blood

\section{Table 1. Non-dialyzable arsenic in haemolysates} from arsine-poisoned rabbits

\begin{tabular}{|c|c|c|c|c|c|c|}
\hline $\begin{array}{l}\text { No. of } \\
\text { exp. }\end{array}$ & $\begin{array}{c}\mathrm{AsH}_{3} \\
\text { conc. } \\
\text { (mg./l.) }\end{array}$ & $\begin{array}{l}\text { Time } \\
\text { of ex- } \\
\text { posure } \\
\text { (min.) }\end{array}$ & $\begin{array}{l}\text { Total } \\
\text { As in } \\
\text { blood } \\
\text { ( } \mu \mathrm{g} . / \\
\mathrm{ml} .)\end{array}$ & $\begin{array}{c}\text { Total } \\
\text { As in } \\
\text { haemo- } \\
\text { lysate } \\
(\mu \mathrm{g} . / \\
3 \mathrm{ml} .)\end{array}$ & $\begin{array}{c}\text { As in } \\
\text { haemo- } \\
\text { lysate } \\
\text { after } \\
\text { dialysís } \\
\text { ( } \mu \text { g./ } \\
\mathbf{3} \text { ml.) }\end{array}$ & $\begin{array}{c}\text { Non-dia- } \\
\text { lyzable } \\
\text { As in } \\
\text { haemo- } \\
\text { lysate } \\
(\%)\end{array}$ \\
\hline 1 & 0.46 & 20 & $13 \cdot 7$ & $12 \cdot 8$ & 12.5 & 98 \\
\hline 2 & 0.46 & 20 & $17 \cdot 2$ & $17 \cdot 0$ & $17 \cdot 7$ & 104 \\
\hline 3 & 0.53 & 20 & - & $15 \cdot 4$ & $9 \cdot 7$ & 63 \\
\hline 4 & 0.46 & 20 & $10 \cdot 6$ & $10 \cdot 8$ & $10 \cdot 7$ & 99 \\
\hline 5 & 0.47 & 20 & $9 \cdot 2$ & 8.9 & $5 \cdot 6$ & 63 \\
\hline 6 & 0.51 & 20 & $15 \cdot 7$ & $16 \cdot 2$ & $13 \cdot 8$ & 85 \\
\hline 7 & 0.47 & 20 & $22 \cdot 7$ & $16 \cdot 8$ & 14.5 & 86 \\
\hline 8 & 0.48 & 20 & 22.4 & $20 \cdot 5$ & $17 \cdot 5$ & 85 \\
\hline 9 & 0.50 & 20 & 31.9 & $24 \cdot 1$ & $13 \cdot 0$ & 54 \\
\hline 10 & 0.46 & 20 & 14.9 & $14 \cdot 7$ & $11 \cdot 5$ & 78 \\
\hline 11 & 0.95 & 20 & $38 \cdot 4$ & $33 \cdot 7$ & $34 \cdot 1$ & 101 \\
\hline 12 & 0.91 & 20 & $40 \cdot 4$ & $37 \cdot 6$ & $31 \cdot 2$ & 83 \\
\hline 13 & 0.75 & 20 & - & $21 \cdot 5$ & 20.9 & 97 \\
\hline 14 & 0.94 & 5 & - & $9 \cdot 8$ & 6.4 & 65 \\
\hline
\end{tabular}

Table 2. Non-dialyzable arsenic in haemolysates from blood of normal rabbits treated in vitro with arsine

\begin{tabular}{|c|c|c|c|c|}
\hline $\begin{array}{l}\text { No. of } \\
\text { exp. }\end{array}$ & $\begin{array}{l}\text { Total As } \\
\text { in blood } \\
(\mu \mathrm{g} . / \mathrm{ml} .)\end{array}$ & $\begin{array}{c}\text { Total As } \\
\text { in haemo- } \\
\text { lysate } \\
(\mu \mathrm{g} . / 3 \mathrm{ml} .)\end{array}$ & $\begin{array}{c}\text { As in } \\
\text { haemo- } \\
\text { lysate after } \\
\text { dialysis } \\
(\mu \mathrm{g} . / 3 \mathrm{ml} .)\end{array}$ & $\begin{array}{c}\text { Non-dia- } \\
\text { lyzable } \\
\text { As in } \\
\text { haemo- } \\
\text { lysate } \\
(\%)\end{array}$ \\
\hline 15 & 10.5 & $9 \cdot 8$ & $5 \cdot 1$ & 52 \\
\hline 16 & $9 \cdot 6$ & $5 \cdot 8$ & $4 \cdot 7$ & 56 \\
\hline 17 & $37 \cdot 6$ & $36 \cdot 4$ & $2 \overline{1} \cdot 8$ & 60 \\
\hline 18 & $48 \cdot 3$ & $51 \cdot 4$ & 27.9 & 54 \\
\hline 19 & $54 \cdot 1$ & $45 \cdot 8$ & $21 \cdot 4$ & 47 \\
\hline 20 & $47 \cdot 9$ & $41 \cdot 4$ & $22 \cdot 2$ & 54 \\
\hline 21 & - & $54 \cdot 3$ & $31 \cdot 0$ & 57 \\
\hline 22 & - & $53 \cdot 3$ & $26 \cdot 2$ & 49 \\
\hline
\end{tabular}

of normal rabbits treated in vitro with arsine (Table 2) clearly show that the fixed As in arsinepoisoned blood can be separated into two distinct fractions. It is noteworthy that in the experiments on the haemolysates from poisoned rabbits the nondialyzable As varied from 54 to $100 \%$ of the total As, while in the experiments on the haemolysates from in vitro poisoned rabbit blood, the non-dialyzable As varied only between 47 and $60 \%$ of the total. It is very tentatively suggested that the less constant and generally higher values found for the 
non-dialyzable As in the in vivo poisoning experiments may have been due to diffusion of dialyzable As out of the erythrocytes and subsequent loss to the tissues or through the kidneys during the period of exposure in the gas chamber.

\section{The nature of the dialyzable fixed arsenic in arsine-poisoned blood}

The method of quantitative separation of arsenate and arsenite developed by Crawford \& Storey (1944) has been applied to an examination of the dialyzable fixed As present in the haemolysate obtained from one arsine-poisoned rabbit and in three haemolysates from normal rabbit blood treated in vitro with arsine. This method, which depends upon the fact that arsenious acid, but not arsenic acid, forms a $\mathrm{CCl}_{4}$-soluble compound when treated with a $\mathrm{CCl}_{4}$ solution of sodium ethyl xanthate, was found to give good recoveries of arsenite and arsenate when these substances were added to normal rabbit blood.

The main bulk of each haemolysate $(50-100 \mathrm{ml}$.), after removal of samples for total As and non-dialyzable As, was dialyzed in a large 'Visking' sausage casing for $24 \mathrm{hr}$. in the refrigerator against two lots of approximately $100 \mathrm{ml}$. of water. The two dialysates were then combined and made up to $250 \mathrm{ml}$. Samples were removed for total As, and 'arsenate' and 'arsenite' determined in the remainder by the xanthate method. As a precaution, the acidified dialysate was extracted three times with $\mathrm{CCl}_{4}$ before extraction with the reagent.

The figures for 'arsenite' and 'arsenate' in the dialysates of the four experiments (Table 3) were obtained from the values actually determined by applying a correction factor derived from the total dialyzable As in the haemolysate and the total As in the combined dialysates. These results show that

Table 3. 'Arsenite' and 'arsenate' in the dialyzable fixed arsenic in arsine-poisoned blood

\begin{tabular}{|c|c|c|c|c|c|}
\hline \multirow[b]{2}{*}{$\begin{array}{l}\text { No. } \\
\text { of } \\
\text { exp. }\end{array}$} & \multirow[b]{2}{*}{$\begin{array}{l}\text { Type of } \\
\text { exp. }\end{array}$} & \multirow{2}{*}{$\begin{array}{c}\text { Total } \\
\text { As in } \\
\text { haemo- } \\
\text { lysate } \\
(\mu \mathrm{g} \cdot / \\
100 \mathrm{ml} .)\end{array}$} & \multirow{2}{*}{$\begin{array}{c}\text { Total dia- } \\
\text { lyzable } \\
\text { As in } \\
\text { dialysate } \\
\text { ( } \mu \mathrm{g} . / \\
100 \mathrm{ml} . \\
\text { haemo- } \\
\text { lysate) }\end{array}$} & \multicolumn{2}{|c|}{$\begin{array}{l}\text { 'Arsenite' and } \\
\text { 'arsenate' as As } \\
\text { in dialysate } \\
\text { ( } \mu \mathrm{g} . / 100 \mathrm{ml} \text {. } \\
\text { haemolysate })\end{array}$} \\
\hline & & & & & \\
\hline 12 & Poisoned rabbit & 1250 & 210 & & 40 \\
\hline $\begin{array}{l}19 \\
20 \\
21\end{array}$ & $\begin{array}{l}\text { Rabbit's blood } \\
\text { poisoned } \\
\text { in vitro }\end{array}$ & $\begin{array}{l}1530 \\
1380 \\
1810\end{array}$ & & & $\begin{array}{r}0 \\
0 \\
29\end{array}$ \\
\hline
\end{tabular}

in both types of experiment a high proportion of the dialyzable fraction of the fixed As behaves towards the xanthate reagent as arsenite.

Evidence for the existence of two forms of nondialyzable arsenic in arsine-poisoned blood

With the object of finding a method of rendering the non-dialyzable As fraction dialyzable, so that its behaviour towards the xanthate reagent could be studied, many preliminary experiments on the stability of this fraction were made.

The stability of the non-dialyzable As in the haemolysate from the blood of a poisoned rabbit to dialysis in the refrigerator against solutions of different $\mathrm{pH}$ was first studied. Over the range $\mathrm{pH}$ 2-11 the non-dialyzable As appeared to be stable for at least 6 days. On the other hand, after 6 days' dialysis at $\mathrm{pH} 1(0.1 \mathrm{~N}-\mathrm{HCl}), 77 \%$ of the normally non-dialyzable As had dialyzed out, while after 6 days at $\mathrm{pH} 13(0 \cdot 1 \mathrm{~N}-\mathrm{NaOH}), 53 \%$ dialyzed. The addition of a little dilute $\mathrm{K}_{3} \mathrm{Fe}(\mathrm{CN})_{6}$ solution caused a large proportion, but not all, to become dialyzable. A smaller proportion was rendered dialyzable by heating the haemolysate to boiling for a few minutes, and about the same proportion by adding pyridine to give a concentration of about $40 \%$.

It was striking that in none of these preliminary, somewhat qualitative, experiments was all the nondialyzable As rendered dialyzable. This suggested the possibility that there might be present in the haemolysates from arsine-poisoned blood two forms of non-dialyzable As differing from one another in stability. This possibility was tested by more quantitative experiments on the conversion of nondialyzable to dialyzable As by the ferricyanide method.

(1) The haemolysate from the blood of an arsine-poisoned rabbit was dialyzed for 3 days against distilled water, the water being changed three times daily. Six $3 \mathrm{ml}$. samples of the dialyzed haemolysate were dialyzed in 'Visking' dialysis sacs in the refrigerator against $5 \% \mathrm{~K}_{3} \mathrm{Fe}(\mathrm{CN})_{6}$. Two sacs were removed each day for the determination of undialyzed As. Four $3 \mathrm{ml}$. samples of the haemolysate were dialyzed against distilled water as controls, the water being changed three times daily. Two samples wene removed after the first day, and the remaining two after the third day for determination of As. Blank determinations on dialysis sacs containing $3 \mathrm{ml}$. of distilled water and dialyzed against $5 \% \mathrm{~K}_{3} \mathrm{Fe}(\mathrm{CN})_{6}$ were carried out.

(2) A second experiment was carried out in an identical manner with the dialyzed haemolysate from normal rabbit blood which had been poisoned in vitro with arsine.

(3) Since in Exps. 1 and 2, owing to a miscalculation in the size of the samples taken for dialysis against ferricyanide, the amounts of As actually estimated were in some cases considerably less than $10 \mu \mathrm{g}$., a third similar experiment was carried out on a dialyzed haemolysate from the blood of a poisoned rabbit, but the samples taken for dialysis against ferricyanide were of such a size as to ensure that at least $20 \mu \mathrm{g}$. As would be estimated.

The results of these three experiments, which are shown in Table 4, make the conclusion almost inescapable that about $70-80 \%$ of the non-dialyzable As differs from the remainder in being readily converted to a dialyzable form by treatment with ferricyanide. 
Table 4. Dialysis against $5 \%$ potassium ferricyanide of 'water-dialyzed' haemolysates from arsinepoisoned blood

\begin{tabular}{|c|c|c|c|c|c|c|}
\hline \multirow[b]{2}{*}{$\begin{array}{c}\text { Type of } \\
\text { exp. }\end{array}$} & \multirow{2}{*}{$\begin{array}{c}\text { Non-dia- } \\
\text { lyzable } \\
\text { As in } \\
\text { haemo- } \\
\text { lysate } \\
(\mu \mathrm{g} . / \\
\mathbf{3} \mathrm{ml} .)\end{array}$} & \multicolumn{3}{|c|}{$\begin{array}{l}\text { Undialyzed As } \\
\text { remaining after } \\
\text { dialysis against } \\
\text { ferricyanide for }\end{array}$} & \multicolumn{2}{|c|}{$\begin{array}{l}\text { Controls. As } \\
\text { after dialysis } \\
\text { against water for }\end{array}$} \\
\hline & & $\overbrace{1 \text { day }}^{(\mu \mathrm{g} . / 3 \mathrm{ml}}$ & $\begin{array}{l}2 \mathrm{dg} \\
\text { l. hac }\end{array}$ & $\begin{array}{l}3 \text { days } \\
\text { lysate) }\end{array}$ & $\begin{array}{l}1 \text { day } \\
(\mu \mathrm{g} \\
\text { haem }\end{array}$ & $\begin{array}{l}3 \text { days } \\
2 \text { ml. } \\
\text { (ysate) }\end{array}$ \\
\hline $\begin{array}{l}\text { In vivo } \\
\text { In vitro } \\
\text { In vivo }\end{array}$ & $\begin{array}{l}20 \cdot 9 \\
26 \cdot 2 \\
29 \cdot 1\end{array}$ & $\begin{array}{r}5 \cdot 6 \\
11 \cdot 4 \\
10 \cdot 6\end{array}$ & $\begin{array}{l}3 \cdot 3 \\
6 \cdot 0 \\
7 \cdot 5\end{array}$ & $\begin{array}{l}3 \cdot 0 \\
8 \cdot 4 \\
6 \cdot 7\end{array}$ & $\begin{array}{l}21 \cdot 0 \\
29 \cdot 6 \\
29 \cdot 5\end{array}$ & $\begin{array}{l}18 \cdot 1 \\
32 \cdot 0 \\
24 \cdot 7\end{array}$ \\
\hline
\end{tabular}

\section{The nature of the labile non-dialyzable arsenic} in arsine-poisoned blood

Certain of the methods described in the preceding section for the conversion of part of the nondialyzable As to the dialyzable form were unsuitable as preliminaries to examination by the xanthate reagent. Kolthoff (1919) showed that in alkaline solution arsenite becomes rapidly oxidized to arsenate. Control experiments conducted in the course of the present work showed in fact that in the presence of blood arsenite is rapidly oxidized to arsenate at $\mathrm{pH} 13$. Conversion at $\mathrm{pH} 1$ was also considered to be unsuitable, since the proportion of non-dialyzable As rendered dialyzable at this reaction was found to vary considerably from experiment to experiment. Conversion in $40 \%$ pyridine was also rejected, since it was considered that the large amount of pyridine present in the dialysate might interfere with the fractionation. However, preliminary experiments showed that both boiling and treatment with ferricyanide would be satisfactory as preliminaries to the examination of the labile non-dialyzable As by the xanthate reagent. Sodium arsenite or arsenate was added to rabbit blood, and after laking with water the haemolysates were boiled or treated with ferricyanide. Examination of the dialysates from these treated haemolysates showed that no conversion of arsenite to arsenate, or vice versa, had occurred.

A haemolysate obtained from the blood of an arsinepoisoned rabbit was freed as completely as possible from dialyzable As by dialysis in the refrigerator for 4 days against seven changes of distilled water. $50 \mathrm{ml}$. of this dialyzed haemolysate were placed in a large 'Visking' dialysis sac which was immersed in a beaker containing about $100 \mathrm{ml}$. of boiling water for $10 \mathrm{~min}$., and then the beaker and dialysis sac were transferred to the refrigerator. After $24 \mathrm{hr}$. the water in the beaker was changed and dialysis continued for a further $24 \mathrm{hr}$. The two dialysates were combined, and after making up to a volume of $250 \mathrm{ml}$., determinations of 'arsenite' and 'arsenate' by the xanthate method, and of total As were carried out.

To a further $45 \mathrm{ml}$. of the original dialyzed haemolysate were added $20 \mathrm{ml}$. of $5 \% \mathrm{~K}_{3} \mathrm{Fe}(\mathrm{CN})_{6}$. After standing at room temperature for $20 \mathrm{~min}$. the mixture was transferred to a dialysis sac and dialyzed for $48 \mathrm{hr}$. in the refrigerator against two $100 \mathrm{ml}$. lots of distilled water. The combined dialysates were made up to $250 \mathrm{ml}$. and determinations of 'arsenite', 'arsenate', and total As carried out.

A second similar experiment was carried out on a haemolysate prepared from normal rabbit blood poisoned in vitro with arsine.

The results (Table 5) show quite clearly that a high proportion of the dialyzable As obtained from the non-dialyzable form by boiling and by ferricyanide treatment behaves towards the xanthate reagent as arsenite.

Table 5. 'Arsenite' and 'arsenate' in dialysates obtained from water-dialyzed haemolysates of arsinepoisoned blood after boiling and after treatment with potassium ferricyanide

\begin{tabular}{|c|c|c|c|c|c|c|}
\hline & \multicolumn{3}{|c|}{ Boiling } & \multicolumn{3}{|c|}{ Ferricyanide } \\
\hline & $\begin{array}{c}\text { Total } \\
\text { As in } \\
\text { dia- } \\
\text { lysate } \\
(\mu \mathrm{g} .)\end{array}$ & $\begin{array}{c}\text { As in } \\
\text { dia- } \\
\text { lysate } \\
\text { as } \\
\text { 'arse- } \\
\text { nite' } \\
(\mu \mathrm{g} .)\end{array}$ & $\begin{array}{c}\text { As in } \\
\text { dia- } \\
\text { lysate } \\
\text { as } \\
\text { 'arse- } \\
\text { nate' } \\
(\mu \mathrm{g} .)\end{array}$ & $\begin{array}{c}\text { Total } \\
\text { As in } \\
\text { dia- } \\
\text { lysate } \\
(\mu \mathrm{g} .)\end{array}$ & $\begin{array}{l}\text { As in } \\
\text { dia- } \\
\text { lysate } \\
\text { as } \\
\text { 'arse- } \\
\text { nite' } \\
\text { ( } \mu \text { g.) }\end{array}$ & $\begin{array}{c}\text { As in } \\
\text { dia. } \\
\text { lysate } \\
\text { as } \\
\text { 'arse- } \\
\text { nate' } \\
\text { ( } \mu \mathrm{g} .)\end{array}$ \\
\hline $\begin{array}{l}\text { In vivo } \\
\text { In vitro }\end{array}$ & $\begin{array}{l}187 \\
190\end{array}$ & $\begin{array}{l}185 \\
168\end{array}$ & $\begin{array}{r}8 \\
17\end{array}$ & $\begin{array}{l}353 \\
179\end{array}$ & $\begin{array}{l}307 \\
153\end{array}$ & $\begin{array}{l}10 \\
18\end{array}$ \\
\hline
\end{tabular}

\section{Experiments with crystalline horse haemoglobin}

Certain of the findings described in the preceding sections have been confirmed in experiments on solutions of crystalline horse haemoglobin treated with high concentrations of arsine.

Preparation of haemoglobin solutions and technique of treatment with arsine. Erythrocytes from oxalated fresh horse blood were washed eight times with $0.9 \% \mathrm{NaCl}$ and then laked by making up to the original volume of the blood with distilled water. This haemolysate was frozen in large centrifuge cups which were then spun until thawing was just complete. After pouring off the supernatant liquid, the sludge, consisting of haemoglobin crystals and stromata, was shaken with $0.9 \% \mathrm{NaCl}$ and the stromata were removed by centrifuging. The concentration of haemoglobin in the solution was determined by the alkaline-haematin method.

A known amount of arsine was introduced into a roundbottomed $3 \mathrm{l}$. flask by displacement of a measured volume of water with a hydrogen-arsine mixture of known arsine content. A measured volume of haemoglobin solution was then rapidly run into the flask from a burette under slight pressure. The flask was shaken continuously for a period of 20-35 min., and any unreacted arsine was subsequently removed by thorough evacuation at the water-pump.

Non-dialyzable fixed arsenic in arsine-treated haemoglobin solutions and the behaviour of the dialyzable arsenic fraction towards the xanthate reagent. Four experiments were carried out as described above in which haemoglobin solutions were gassed for varying periods with varying concentrations of arsine. From each reaction mixture measured 
samples were removed for the determination of total fixed As and of non-dialyzable fixed As. The results (Table 6) indicate that as was the case with

Table 6. Non-dialyzable arsenic in solutions of horse haemoglobin treated with arsine

\begin{tabular}{|c|c|c|c|c|c|}
\hline $\begin{array}{l}\text { Reac- } \\
\text { tion } \\
\text { period } \\
\text { (min.) }\end{array}$ & $\begin{array}{l}\text { Haemo- } \\
\text { globin } \\
\text { content } \\
\text { of solu- } \\
\text { tion } \\
\text { (g./ } \\
100 \mathrm{ml} \text {.) }\end{array}$ & $\begin{array}{c}\mathrm{AsH}_{3} \\
\text { added } \\
\text { (mg./ } \\
100 \mathrm{ml} .)\end{array}$ & $\begin{array}{c}\text { Total } \\
\text { As in } \\
\text { reaction } \\
\text { mixture } \\
(\mathrm{mg} \cdot / \\
100 \mathrm{ml} .)\end{array}$ & $\begin{array}{c}\text { Non-dia- } \\
\text { lyzable } \\
\text { As in } \\
\text { reaction } \\
\text { mixture } \\
(\mathrm{mg} \cdot / \\
100 \mathrm{ml} .)\end{array}$ & $\begin{array}{c}\text { Non-dia- } \\
\text { lyzable } \\
\text { As as } \\
\% \text { of } \\
\text { total As }\end{array}$ \\
\hline $\begin{array}{l}20 \\
20 \\
\mathbf{3 5} \\
\mathbf{3 5}\end{array}$ & $\begin{array}{l}1 \cdot 28 \\
1 \cdot 28 \\
2 \cdot 50 \\
2 \cdot 50\end{array}$ & $\begin{array}{r}11 \cdot 3 \\
11 \cdot 3 \\
178 \cdot 0 \\
178 \cdot 0\end{array}$ & $\begin{array}{c}9 \cdot 59 \\
9 \cdot 98 \\
32 \cdot 3 \\
51 \cdot 6\end{array}$ & $\begin{array}{c}3.95 \\
3 \cdot 98 \\
10 \cdot 7 \\
18 \cdot 3\end{array}$ & $\begin{array}{l}41 \\
40 \\
33 \\
35\end{array}$ \\
\hline
\end{tabular}

poisoned blood, a proportion of the total fixed As is in a non-dialyzable form. This proportion was somewhat lower than that found for blood.

'Arsenite' and 'arsenate' in the dialyzable fractions in each of the four experiments were determined in the following manner: One volume of the reaction mixture $(50-150 \mathrm{ml}$.) was dialyzed for $24 \mathrm{hr}$. in the refrigerator in a 'Visking' dialysis sac against approximately 2 vol. of water. After adjustment of the dialysate to a suitable volume, measured samples were removed for the determination of total As and of 'arsenite' and 'arsenate' by the xanthate method. In the four experiments $97 \cdot 0$, $97 \cdot 2,97.5$ and $96.4 \%$ respectively of the total As in the dialysate was found to behave towards the xanthate reagent as arsenite. -

\section{SUMMARY}

1. $50-100 \%$ of the fixed arsenic in the blood of arsine-poisoned rabbits is in a non-dialyzable form.

2. 47-60\% of the arsenic fixed in normal rabbit blood treated in vitro with small concentrations of arsine in the presence of excess air is in a nondialyzable form.

3. Of the fixed arsenic present in solutions of crystalline horse haemoglobin after treatment with high concentrations of arsine in the presence of excess air, from 33-41\% was found to be nondialyzable.

4. The dialyzable arsenic present in the blood of arsine-poisoned rabbits, in normal rabbit blood and in solutions of crystalline horse haemoglobin treated in vitro with arsine, was almost completely in a form which behaved as arsenite towards the xanthate reagent.

5. The non-dialyzable arsenic present in rabbit blood poisoned in vitro and in vivo with arsine is stable between $\mathrm{pH} 2$ and 11, but is partially converted to a dialyzable form at $\mathrm{pH} 1$ and 13. Partial conversion to a dialyzable form is also effected by treatment with pyridine, ferricyanide, or by boiling.

6. Quantitative experiments on the effect of ferricyanide on the non-dialyzable fraction showed that only 70-80\% of this fraction could be rendered dialyzable. It is concluded that there are present two forms of non-dialyzable arsenic.

7. Most of the non-dialyzable arsenic rendered dialyzable by ferricyanide or boiling behaves as arsenite towards the xainthate reagent. The 'labile' non-dialyzable arsenic fraction is therefore probably in the trivalent form.

The authors wish to acknowledge their gratitude to the Chief Scientific Officer, Ministry of Supply, for permission to publish this work. They are also indebted to Dr G. A. Levvy for valuable assistance and advice in carrying out the animal experiments, and to Dr Ena Brown and Mrs Mary Anderson for assistance in other phases of the work. Certain of the expenses of this work were defrayed from grants to the authors from the Earl of Moray Research Fund of this University.

\section{REFERENCES}

Crawford, T. B. B. \& Storey, I. D. E. (1944). Biochem. J. 38, 195.

Eulenberg, H. (1865). Die Lehre von den schädlichen und giftigen Gasen. Braunschweig.

Gebert, Fr. (1937). Biochem. Z. 293, 157.

Heubner, W. \& Wolff, K. (1936). Arch. exp. Path. Pharmak. $181,149$.

Joachimoglu, G. (1916). Arch. exp. Path. Pharmak. 80, 8.

Kolthoff, I. M. (1919). Pharm. Weekbl. 56, 621. (Quoted from Brit. Chem. Abst. 1919, 2, 522.)
Labes, R. (1928). Arch. exp. Path. Pharmak. 131, 322.

Labes, R. (1937). Kolloidzschr. 79, 1.

Levvy, G. A..(1943). Biochem. J. 37, 598.

Meissner, R. (1913). Z. exp. Path. Ther. 13, 284.

Naunyn, B. (1868). Arch. Anat. Physiol. p. 401.

Stricker (1882). Inaug. Dissert. Bonn. (Quoted by N. W. Jones, J. Amer. Med. Ass. 1907, 48, 1099.)

Thauer, R. (1934). Arch. exp. Path. Pharmak. 176, 531.

Wolff, K. (1936). Biochem. Z. 288, 79. 